\title{
Woody Vegetation Utilisation in Tembe Elephant Park, Kwazulu-Natal, South Africa
}

\author{
Jerome Y. Gaugris ${ }^{1,2}$, Caroline A. Vasicek ${ }^{2} \&$ Margaretha W. van Rooyen ${ }^{3}$ \\ ${ }^{1}$ Centre for Wildlife Management, University of Pretoria, Pretoria, South Africa \\ ${ }^{2}$ Flora Fauna \& Man, Ecological Services Ltd., Road Town/Tortola, British Virgin Island \\ ${ }^{3}$ Ekotrust cc. 272 Thatcher's Field, Lynwood, Pretoria, South Africa \\ Correspondence: Jerome Y. Gaugris, Centre for Wildlife Management, University of Pretoria, 0002 Pretoria, \\ South Africa. Tel: 27-72-266-9902. E-mail: jeromegaugris@florafaunaman.com
}

Received: March 13, 2014 Accepted: April 20, 2014 Online Published: April 24, 2014

doi:10.5539/ijb.v6n3p24 URL: http://dx.doi.org/10.5539/ijb.v6n3p24

\begin{abstract}
A survey of woody plant species utilisation by large (excluding elephants), medium and small browsers,man and "natural damage", was conducted in nine vegetation units of Tembe Elephant Park, KwaZulu-Natal, South Africa. Woody species use and canopy removal were evaluated within two age ranges, (a) recent, $\leq 12$ months prior to study and (b) old, > 12 months prior to the study. The results show that recent canopy removal by medium and small browsers was intensive and generally represented one third of height classes available to the agents which were consistently used withinall vegetation types. The overall utilisation pattern indicated that medium and small browsers may be removing the regeneration classof the woody plants layer. Natural damage was found to be considerable and it was hypothesized that it may be linked and possibly amplified by prior elephant utilisation. In conclusion, it is possible to suggest that the regular use of the sapling level by small and medium browsers could promote woodland to grassland retrogression, as was found in east Africa under high densities of animals.
\end{abstract}

Keywords: browsers, Maputaland, sand forest, tree utilisation, woodland

\section{Introduction}

Numerous ecological problems have been documented regarding over-concentration of animals; in small or large, fenced or even open systems (Walpole et al., 2004; Western, 2007; Eckhardt et al., 2000; Mosugelo et al., 2002). Among them is the transformation of a woodland landscape into shrubby grassland, or the suppression of woody vegetation growth (Western \& Maitumo, 2004). Growing animal populations confined in reserves in Africa has come to the forefront of conservation issues because public, scientific, and conservation opinions are divided on how to manage this problem (Lombard et al., 2001; van Aarde \& Jackson, 2007).

When the vegetation type supporting growing animal populations is endangered, poorly known or sensitive to utilisation, understanding the impact of animal populations is essential (Lombard et al., 2001; O'Connor et al., 2007). In Tembe Elephant Park (Tembe), a South African reserve, Sand Forest is considered one of the most valuable vegetation types of the Maputaland - Pondoland - Albany hotspot of biodiversity (Smith et al., 2006). In Tembe, conservation authorities indicated that Sand Forest conservation prevails over animal conservation targets (Matthews, 2006). However, subsequent to the park's fencing in 1989 and successful conservation measures, without limiting larger carnivores, animal populations have grown and appeared unlimited by density dependence (Guldemond \& van Aarde, 2007). This is a concern as Sand Forest has been shown to react to large herbivore utilisation (Gaugris \& van Rooyen, 2008), and requires that utilisation levels be established to understand the pressure and potential impact.

As Sand Forest origin remains in debate and because arguments exists that it may develop from a woodland succession sequence (Gaugris \& van Rooyen, 2008), the present study investigated woody vegetation utilisation by small to large mammalian browsing herbivores in woodlands and Sand Forest of Tembe (excluding elephants) , to quantify utilisation. Human use although anecdotal is also reported. Finally the occurrence of what can be considered as "natural damage" is considered. These aspects are examined by evaluating general woody species utilisation and canopy removal within two different periods ( $\leq 12$ months prior to the study and $>12$ months prior to the study) and considering the implications of results observed. 


\section{Methodology}

\subsection{Objectives of the Study}

The present study was undertaken to measure the utilisation of woody species in a fenced off conservation area. The study was considered urgent as growing numbers of browsing mammalian herbivores were considered to have a significant impact on the regeneration of woody plant species. The present study is therefore a description of the measured utilisation levels of woody plants by small to large herbivores (excluding elephants).

\subsection{Study Area}

The study area lies in Maputaland, KwaZulu-Natal, South Africa. Tembe's 30,000 ha (proclaimed in 1983) were completely fenced in 1989 . Tembe is characterised by sandy plains interspersed with ancient littoral dunes and a north flowing swamp (Muzi Swamp) along the park's eastern boundary. Tembeis covered by a mixture of habitats types such as grasslands, woodlands and Sand Forest patches (Matthews et al., 2001). Summers are hot, wet, and humid, while winters are cool to warm and dry. The mean annual rainfall is $700 \mathrm{~mm}$ (Gaugris, 2008).

Tembe's larger mammalian herbivore populations are composed of the following species (re-established species are marked with an asterisk) with the numbers in brackets representing 2000 census - 2005census (Matthews, 2006):

- $\quad$ African elephant Loxodonta africana (130 - 179 (195 (Note 1))

- White rhinoceros* Ceratotheriumsimum (35 - 43)

- $\quad$ Black rhinoceros* Dicerosbicornis $(22-20)$

- $\quad$ Giraffe* Giraffacamelopardalis (100 - 131)

- $\quad$ Hippopotamus Hippopotamusamphibius (14 - 20)

- $\quad$ Plain's zebra* Equusquagga (200 - 176)

- $\quad$ Eland* Tragelaphusoryx (40 - 0)

- Buffalo Syncerus caffer (60 -100)

- $\quad \mathrm{Kudu}^{*}$ Tragelaphusstrepsiceros (290 - 532)

- Blue wildebeest* Connochaetestaurinus (130 - 434)

- Waterbuck* Kobus ellipsiprymnus (360 - 419)

- Impala* Aepycerosmelampus (600 - 694)

- $\quad$ Nyala Tragelaphusangasii (300 - 1800)

- $\quad$ Bushbuck Tragelaphus scriptus (unknown - 40)

- $\quad$ Reedbuck Reduncaarundinum (880 - 268)

- $\quad$ Grey duiker Sylvicapragrimmia (unknown - 200)

- $\quad$ Red duiker Cephalophus natalensis (unknown - 400)

- $\quad$ Suni Neotragusmoschatus (estimated $>500$ )

- Warthog Phacochoerus africanus (260 - 300)

- $\quad$ Bush pig Potamochoerus porcus (unknown)

\section{Methods}

\subsection{Fieldwork}

A total of 135 rectangular plotsof density-dependent size ( $15 \mathrm{~m}$ by $2 \mathrm{~m}$ to a maximum of $45 \mathrm{~m}$ by $19 \mathrm{~m}$ ) placed throughout Tembe by stratified random sampling were surveyed between May and October 2004. Plots were located at least $50 \mathrm{~m}$ away from management tracks and $100 \mathrm{~m}$ away from tourist tracks.

Plots were divided into two halves lengthwise. All woody individuals (defined as plants with an erect to scrambling growth form and ligneous trunk) were identified to the species in the first half, but only individuals' $\geq 0.4 \mathrm{~m}$ tall were recorded on the return leg. Live and dead stems were counted and diameters (D) measured at $30 \mathrm{~cm}$ or above the basal swelling. Plant height $(\mathrm{H})$ and height to base of the canopy (HBC - defined as the height where the larger lowest branches were found) were measured, followed by the largest canopy diameter (D1) and the canopy diameter perpendicular (D2) to D1. Standing dead trees were measured, while fallen dead trees were reconstructed using best fit relationships based on live trees. 
Utilisation was evaluated for each plant and each utilisation episode was scored separately. The following parameters were recorded for each plant (Figure 1):

- $\quad$ Plant state;

- Utilisation type;

- $\quad$ Presumed agent for the observed utilisation event;

- Utilisation event age;

- Estimated percentage of material removed (canopy/bark/roots ...) by utilisation event;

- Growth response to the damage/utilisation.

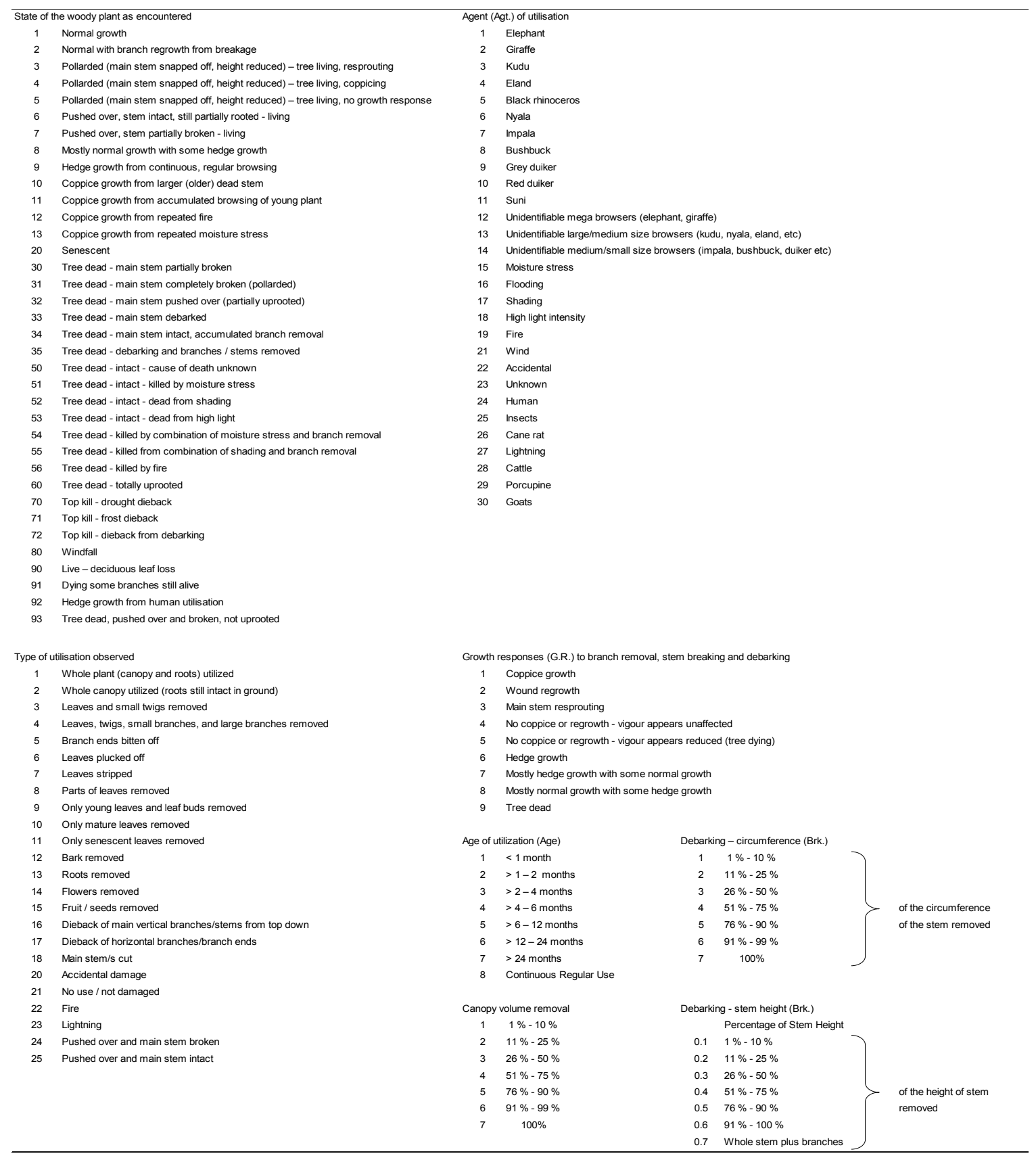

The coding is derived from a code database used for other studies in KwaZulu-Natal, Northern Maputaland, South Africa, and only the codes relevant to the present study are displayed

Figure 1. Copy of the data capture coding sheet used for the study 
Plants were assigned to one of eight height classes $(<0.1 \mathrm{~m}, 0.1$ to $<0.5 \mathrm{~m}, 0.5$ to $<1.5 \mathrm{~m}, 1.5$ to $<3.0 \mathrm{~m}, 3.0$ to $<5.0 \mathrm{~m}, 5.0$ to $<8.0 \mathrm{~m}, 8.0$ to $<12 \mathrm{~m}, \geq 12 \mathrm{~m}$ ) representative of vegetation structure (Gaugris \& van Rooyen, 2011). Utilisation events affecting only canopy volume were distinguished from those representing overall utilisation events (including canopy removal, bark damage, stem or branch breakages, uprooting and other types of damage). Canopy volume removal events were separated between recent events (12 months prior to fieldwork), and old events, for all older events.All analyses were conducted for each agent category for each vegetation unit:

- $\quad$ Large browsers (giraffe)

- Medium browsers (kudu, eland, black rhinoceros)

- $\quad$ Small browsers (suni, red duiker, common duiker, nyala, impala, bushbuck)

- Man

- Natural damage: considered as all instances where elephant or otheragent'sutilisation couldbe excluded and where a natural cause (wind, drought, fire, lightning or light conditions ...) could be considered as most likely reason for observed damage.

The range of height classes available to an agent was all height classes where any utilisation event was documented for that agent during our study. It was calculated as the sum of height classes for all woody species with potential for use per vegetation unit for the agent. For example if six woody species were sampled and known to be used by the agent, and all eight height classes known to have been used by the agent for these species during our study, 48 size classes are considered as available in the vegetation type. However, if the agent can only access the lower four size classes, only 24 size classes were available to the agent.

Available canopy volume and canopy volume removal per height class per woody species per vegetation unit were estimated using Walker's method of 1976. The number of height classes where canopy removal events by an agent was observed was counted at vegetation unit level and expressed as a percentage of total number of height classes available to that agent. The number of height classes where at least $50 \%$ of the canopy volume was removed was calculated similarly per agent at vegetation unit level.

\section{Results}

The Sand Forest classification in Gaugris and van Rooyen (2008) was followed. A total of 168 species were encountered (84\% of Tembe's documented woody species) through measurement of 12,915 woody plants.

\subsection{Sand Forest Association}

In the Sand Forest association and Afzeliaquanzensis clumps, medium and small browsers affected 20 to $76 \%$ of woody species during the recent period (Table 1). The older canopy removal values showed that natural damage affected the greatest number of woody species (40 to $78 \%$ of species). Utilisation marks appeared less noticeable after 12 months for medium (40 to 60\% less species appearing as used) and small browsers (88 to $100 \%$ less species appearing as used). 
Table 1. The number of woody species utilised by various agents in the vegetation associations of Tembe Elephant Park

\begin{tabular}{|c|c|c|c|c|c|c|c|c|c|c|}
\hline \multirow{3}{*}{$\begin{array}{l}\text { No. of Species sampled } \\
\text { No. of Species used by }\end{array}$} & \multirow[b]{3}{*}{ Age } & \multirow[b]{3}{*}{ Type } & \multicolumn{2}{|c|}{$\begin{array}{c}\text { Afzeliaquanzensis } \\
\text { clumps } \\
\text { (VT 01.1.1) }\end{array}$} & \multicolumn{2}{|c|}{$\begin{array}{l}\text { Short Sand } \\
\text { Forest } \\
\text { (VT 01.2.1) }\end{array}$} & \multicolumn{2}{|c|}{$\begin{array}{l}\text { Tall Sand } \\
\text { Forest } \\
\text { (VT 01.2.2) }\end{array}$} & \multicolumn{2}{|c|}{$\begin{array}{l}\text { Mature Sand } \\
\text { Forest } \\
\text { (VT 01.2.3) }\end{array}$} \\
\hline & & & 25 & & 60 & & 71 & & 53 & \\
\hline & & & No & $(\%)$ & No & $(\%)$ & No & $(\%)$ & No & $(\%)$ \\
\hline \multirow[t]{3}{*}{ Large Browsers } & Recent & $\mathrm{CV}$ & 0 & 0.0 & 0 & 0.0 & 0 & 0.0 & 0 & 0.0 \\
\hline & Old & $\mathrm{CV}$ & 0 & 0.0 & 1 & 1.7 & 0 & 0.0 & 1 & 1.9 \\
\hline & All ages & $\mathrm{OU}$ & 0 & 0.0 & 1 & 1.7 & 0 & 0.0 & 1 & 1.9 \\
\hline \multirow[t]{3}{*}{ Medium Browsers } & Recent & $\mathrm{CV}$ & 5 & 20.0 & 25 & 41.7 & 33 & 46.5 & 20 & 37.7 \\
\hline & Old & $\mathrm{CV}$ & 3 & 12.0 & 11 & 18.3 & 20 & 28.2 & 8 & 15.1 \\
\hline & All ages & $\mathrm{OU}$ & 5 & 20.0 & 28 & 46.7 & 37 & 52.1 & 27 & 50.9 \\
\hline \multirow[t]{3}{*}{ Small Browsers } & Recent & $\mathrm{CV}$ & 19 & 76.0 & 25 & 41.7 & 35 & 49.3 & 20 & 37.7 \\
\hline & Old & $\mathrm{CV}$ & 0 & 0.0 & 2 & 3.3 & 4 & 5.6 & 0 & 0.0 \\
\hline & All ages & $\mathrm{OU}$ & 19 & 76.0 & 25 & 41.7 & 38 & 53.5 & 22 & 41.5 \\
\hline \multirow[t]{3}{*}{ Man } & Recent & $\mathrm{CV}$ & 0 & 0.0 & 0 & 0.0 & 0 & 0.0 & 0 & 0.0 \\
\hline & Old & $\mathrm{CV}$ & 0 & 0.0 & 2 & 3.3 & 4 & 5.6 & 0 & 0.0 \\
\hline & All ages & $\mathrm{OU}$ & 0 & 0.0 & 2 & 3.3 & 5 & 7.0 & 0 & 0.0 \\
\hline \multirow[t]{3}{*}{ Natural Damage } & Recent & $\mathrm{CV}$ & 0 & 0.0 & 12 & 20.0 & 17 & 23.9 & 5 & 9.4 \\
\hline & Old & $\mathrm{CV}$ & 10 & 40.0 & 47 & 78.3 & 51 & 71.8 & 28 & 52.8 \\
\hline & All ages & $\mathrm{OU}$ & 10 & 40.0 & 51 & 85.0 & 52 & 73.2 & 29 & 54.7 \\
\hline
\end{tabular}

Values are given for canopy removal (number of species where a percentage of canopy volume (CV) was removed) for the two periods evaluated (Recent: within 12 months prior to the study and Old: $>12$ months prior to the study) and for the overall utilisation $(\mathrm{O} \mathrm{U})$, including all utilisation events, but time was undetermined.

The overall utilisation analysis showed that small browsers are the greatest users in the Afzeliaquanzensis clumps. However, in the Sand Forest association, marks from natural damage appeared to affect more woody species than any other agents (Table 1). Human activity signs were old.

During the recent period, medium browsers utilised up to $25.91 \%$ of height classes available to them (Table 2). Small browsers used the greatest part of the canopy available to them in Sand Forest (up to $60.47 \%$ of height classes available). Canopy removal by natural damage was low. In the old period, canopy removal marks from small and medium browsers appeared to disappear with time (Table 2). Human-linked canopy removal took place in the past (Table 2). Signs of canopy removal by natural damage accumulated over time, and up to $55 \%$ of available height classes were "used" in Short Sand Forest. 
Table 2. The number and percentage of height classes (HC) utilised by the various agents in the Sand Forest association of Tembe Elephan t Park

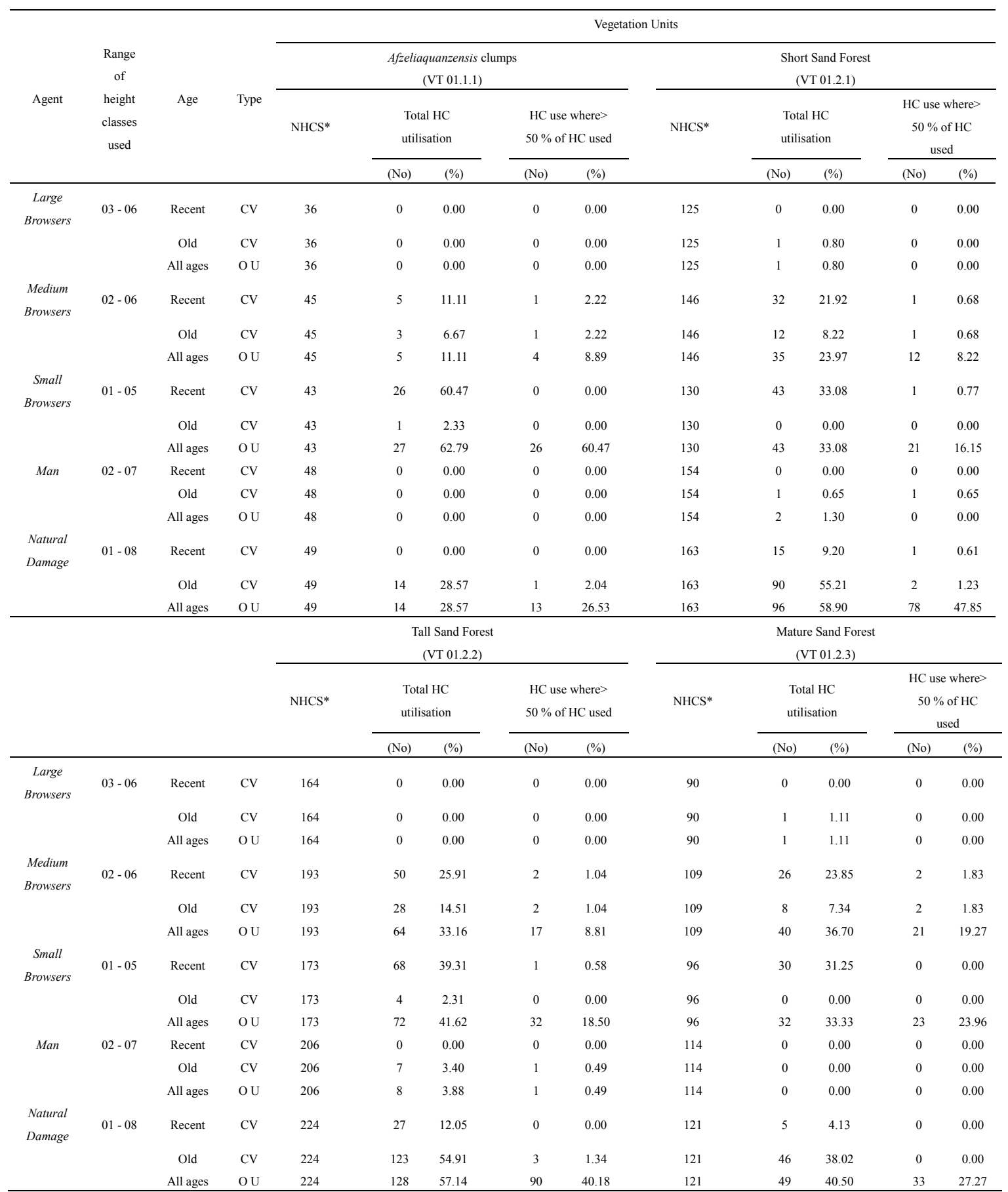

NHCS* = Number of height classes sampled in the range used by the agent;

$\mathrm{HC}=$ Height Classes;

No. $=$ Number.

The number of height classes utilised is represented range utilised by the agent, the number of height classes in that range where utilisation of at least $50 \%$ of the height class was observed for at least one species. Values are given for canopy removal utilisation events $(\mathrm{CV})$ for the two periods evaluated (Recent: within 12 months prior to the study and Old: $>12$ months prior to the study) and for the overall utilisation $(\mathrm{O} U)$, including all utilisation events, but time was undetermined.

In terms of overall utilisation, values mirrored those of old canopy removal, although the percentage of height 
classes used was usually higher for all agents (Table 2), especially when considering the number of height classes where utilisation affected $\geq 50 \%$ of a height class canopy volume. More than $25 \%$ of height classes lost $>$ $50 \%$ of their volume through natural damage.

\subsection{Woodland Vegetation Group}

Recent woody species use was greatest for small and medium browsers (Table 3). Small browsers used more species in Closed Woodland Thicket and Sparse Woodland on Sand than any other agent, and used $\geq 50 \%$ of woody species available in all woodland units. Natural damage affected less woody species than other agents in most instances. When considering old canopy removal, utilisation signs by medium and small browsers were disappearing. However, $>50 \%$ of woody species showed old natural damage signs in three woodland vegetation types.

Table 3. The number of woody species utilised by the various agents in the vegetation associations of Tembe Elephant Park

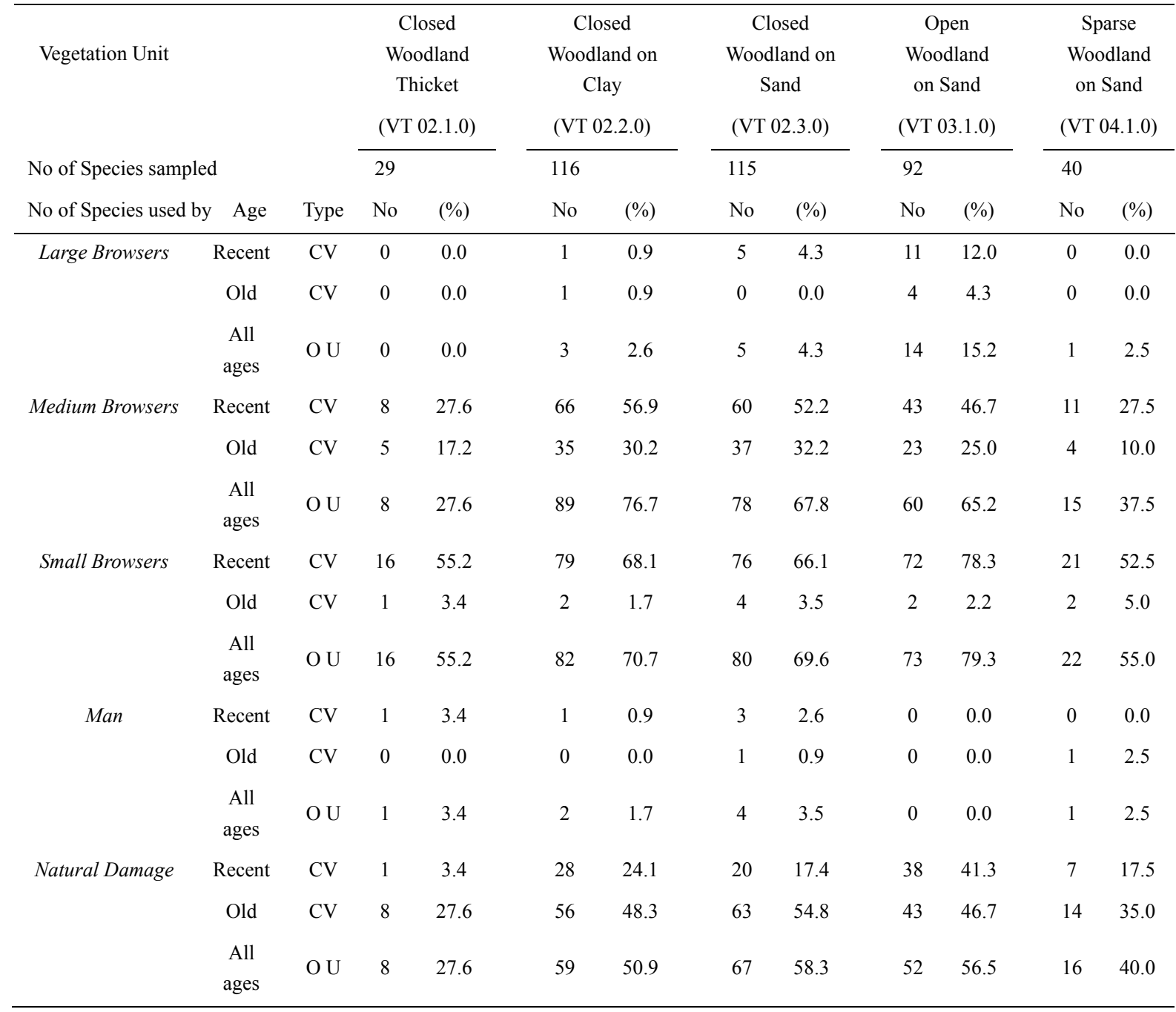

Values are given for canopy removal (number of species where a percentage of canopy volume (CV) was removed) for the two periods evaluated (Recent: within 12 months prior to the study and Old: > 12 months prior to the study) and for the overall utilisation $(\mathrm{O} \mathrm{U})$, including all utilisation events, but time was undetermined.

The overall woody species utilisation showed that the medium browsers used mainly the Closed Woodlands on Clay and Sand and the Open Woodland on Sand (more than 50\% of available woody species). Overall utilisation by small browsers was consistently $>50 \%$ of sampled woody species in all woodland units. Natural damage affected $>50 \%$ of woody species in three woodland units. Recent signs of human utilisation appeared in Closed 
Woodlands.

Small browsers affected the greatest number of height classes (Table 4) followed by natural damage and medium browsers. Utilisation by large browsers was seldom encountered. Natural damage affected a substantialnumber of height classes where canopy removal was $\geq 50 \%$ in the Closed Woodland on Sand and Clay, the Open Woodland on Sand and the Sparse Woodland on Sand. Old canopy removal events followed similar trends as Sand Forest, whereby signs of utilisation by medium and small browsers tended to disappear. Natural damage canopy removal affected approximately a third of height classes throughout the Woodlands.

Table 4. The number and percentage of height classes (HC) utilised by the various agents in the Woodland association of Temb e Elephant Park

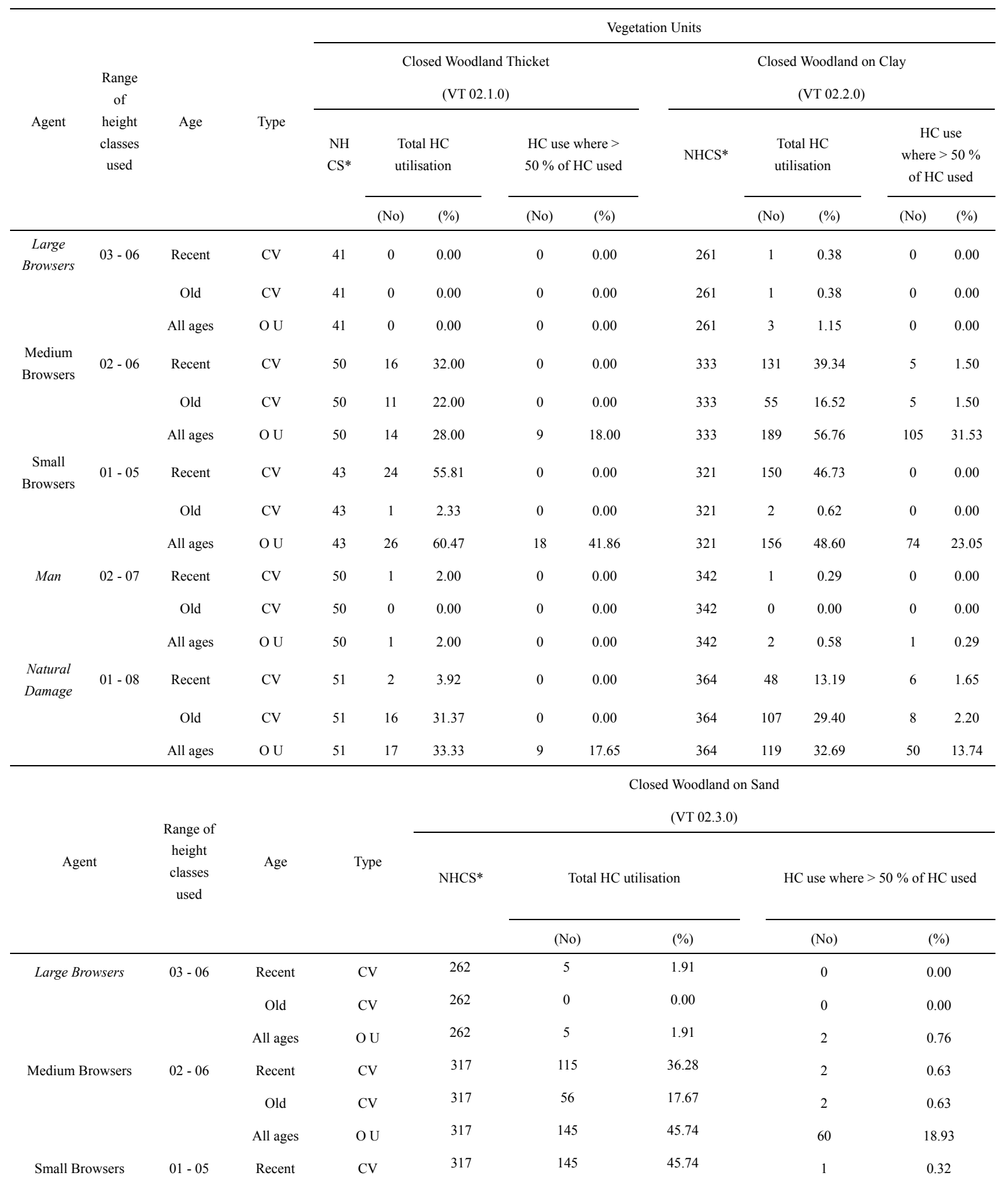




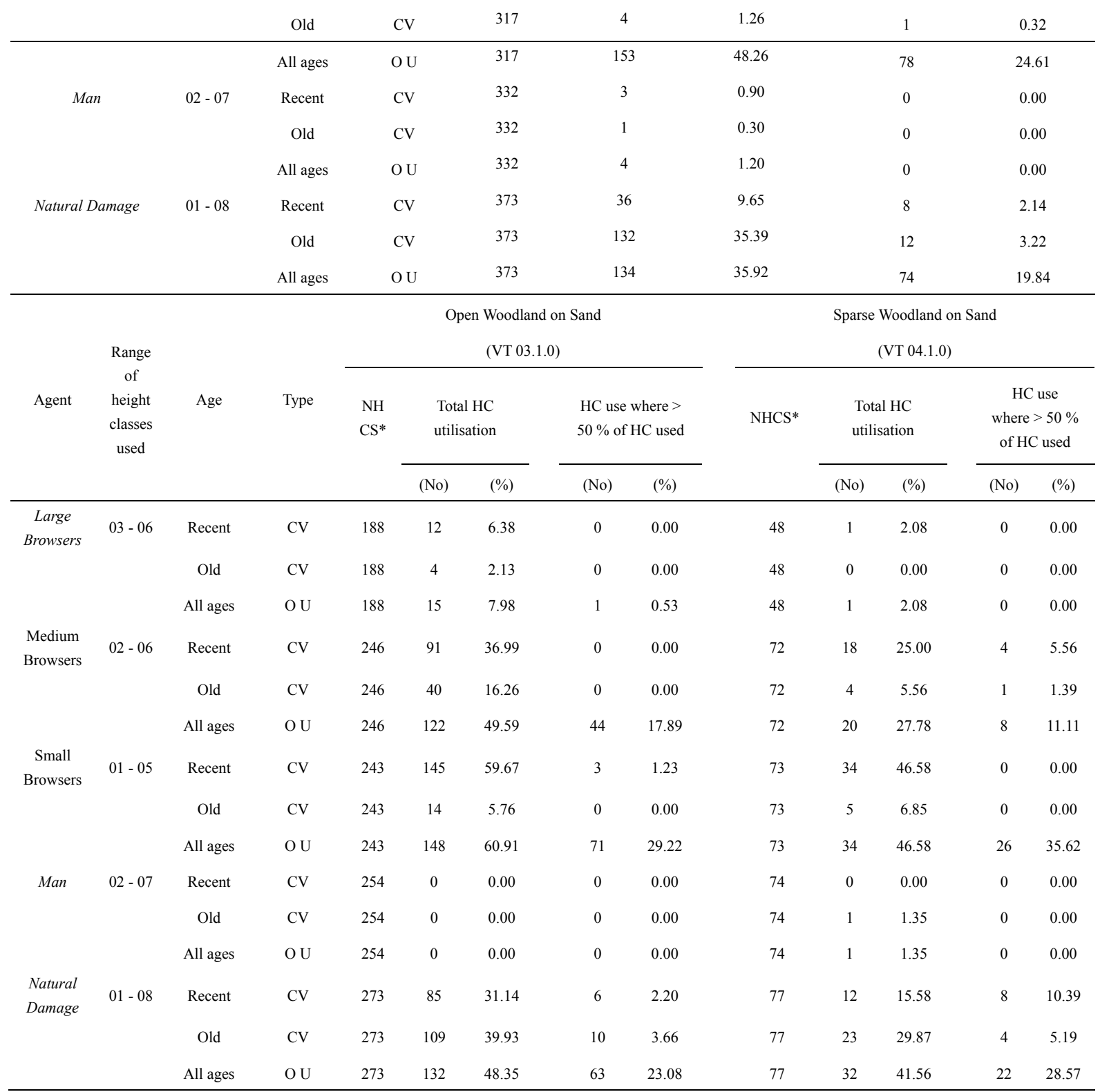

NHCS* = Number of height classes sampled in the range used by the agent;

$\mathrm{HC}=$ Height Classes;

No $=$ Number.

The number of height classes utilised is represented in three ways, a total number of height classes utilised within the range utilised by the agent, the number of height classes in that range where utilisation of at least $50 \%$ of the height class was observed for at least one species. Values are given for canopy removal utilisation events (CV) for the two periods evaluated (Recent: within 12 months prior to the study and Old: > 12 months prior to the study) and for the overall utilisation (O U), including all utilisation events, but time was undetermined.

Overall utilisation values were generally higher than those for canopy removal and the percentage of height classes where at least $50 \%$ of the individuals' available canopy was used was noticeably higher, especially from natural damage (19.48\%) in Sparse Woodland on Sand (Table 4).

\section{Discussion}

While utilisation of trees by elephant is easily observed and has previously been informedfor Tembe (Guldemond \& van Aarde, 2007), medium and small mammalsbrowsing, less easily observed, had not yet been considered. Results indicate that utilisationproved quite intense, although this should not be surprising. A long 
term study in Zululand in Ithala Game reserve (Ithala) observed that browsers and "natural damage" generate three times more impact than elephants, and that the combined impact, over a period of eight years changed both woody species composition and population structures (Wiseman et al., 2004). In all Tembe's Woodlands and to a lesser extent in Sand Forest, small and medium browsers utilised a sizeable portion of available height classes (generally $1 / 3$ to $2 / 3$ of height classes available). Considering these animals' size, the height classes utilised are the smaller ones, which are important for recruitment, such as seedlings and saplings. In Ithala, the combination of elephants and browsers pressure was such that plant species composition changed from species with climax state lifecycle traits (long lived, low recruitment) to more pioneer like species (high recruitment, shorter lifespans ) and also promoted the recruitment of less desirable browse species (Wiseman et al., 2004). Other studies have shown that small mammals herbivory is usually not a limiting factor on its own, although it slows regeneration in cases of high densities (Barnes, 2001; Walpole et al., 2004; Western \& Maitumo, 2004; Western, 2006). In Kenya's Masaai Mara National Reserve, $73 \%$ of woody species were utilised by small browsers, which changed species composition and abundance andfacilitated some invasive species (Walpole et al., 2004). In Botswana, small to medium browsers were considered responsible for changing vegetation morphology (Styles \& Skinner, 2001). The overall utilisation levels by small and medium browsers in Tembe are approaching Kenyan values or even exceeding them in some vegetation types. Therefore, the risk that further small and medium browser population increases would lead to homogenisation of some vegetation units cannot be discarded. Utilisation of woodlands in Tembe already showed that elephants homogenised Open Woodlands, with a risk of forcing succession towards Sparse Woodlands (Guldemond \& Van Aarde, 2007). We consider that elephant utilisation assisted by the heavy smaller browser utilisation in Tembe's woodland conditions seenhere is likely to push succession from dense woodlands to sparse ones. This is likely to progressin much the same ways as happenedin East Africa (Western \& Maitumo, 2004; Birkett \& Stevens-Wood, 2005) unless a management action is taken to limit herbivore populations.

The question of mark accumulation appears quite straightforward. In an unfenced situation, natural migratory movements of animal populations, following rainfall and food availability afford plants time to recover after utilisation events (van Aarde \& Jackson, 2007; Wiseman et al., 2004). Likewise, low animal population numbers make repeated use a rare event, and not the norm. However, in Tembe, fences restrict migratory movements, and the size of the park does not allow simulated migratory movements (van Aarde \& Jackson, 2007), therefore, repeated utilisation events appear unsurprising unless it exceeds what can be considered as normal considering woody decay rates (Sheil \& Salim, 2004). Medium and small browsers utilise many height classes but their actions appear to leave little durable signs of utilisation, which is logical as they tend to defoliate rather than break. Comparatively, elephants, which usually defoliate by breaking branches, stems, or even uprooting whole trees (Wiseman et al., 2004; O'Connor et al., 2007) leave a long-lasting imprint on vegetation that would be observed for long periods. Natural damage marks accumulation is, however, a puzzle.

"Natural damage" intensity was generally a concern. This includes all natural phenomenon that can potentially "damage" or even kill trees (wind, fire, lightning, moisture conditions, drought, light conditions, disease, etc.), which are part of a natural system under normal conditions or subsequent to catastrophic events (Lindenmayer et al., 2006). In Tembe's forests and woodlands, natural damage affects a considerable number of species (27 to $58 \%$ of species in woodlands and 40 to $85 \%$ of species in Sand Forest) in an obvious manner (32 to $41 \%$ of height classes available in woodlands and 28 to $59 \%$ of height classes available in Sand Forest). This aspect was also established in Ithalawhere natural damage was considered to represent $37 \%$ of all utilisation events (Wiseman et al., 2004). Of concern here is that marks appear to also accumulate over time (Tables 1, 2, 3, 4) at a rate that must exceed what it should be for a natural system in the absence of a natural disturbance in both Sand Forest and woodlands. While it is acknowledged that marks observation is influenced by wood decay rate (Sheil \& Salim, 2004) and that in slow decay areas, marks can be observed for much longer periods and therefore falsely give impression that marks accumulate, in Short Sand Forest, $85 \%$ of woody species are affected by "natural damage" and $55.00 \%$ of available height classes displayed evidence of canopy removal (Table 2). This appears extremely high for a vegetation type where fire hardly occurs and where wind should have not much effect because of large tall trees absence (Izidine et al., 2003; Matthews, 2006). As the plants abundance and Short Sand Forest vegetation height make it particularly suited to elephant utilisation, akin to thickets in Addo Elephant Park (Lombard et al., 2001), in the present study, considering utilisation levels, we hypothesise that "natural damage" marks observed may be by default promoted by elephant browsing in the vegetation type.

\section{Conclusion}

In conclusion, as demonstrated for other areas, small and medium mammalian browsers appear to have a considerable influence on all vegetation types of Tembe. Although this impact appears to rarely last for more 
than a year in terms of canopy volume removal (defoliation), observed levels of use are close to levels measured elsewhere that were followed by a retrogression sequence with significant associated vegetation changes. As elephant impact is also considered significant in Tembe (Gaugris \& van Rooyen, 2011; Gaugris et al., 2012), a clear danger exists of forcing Tembe's vegetation into a phase of rapid changes. Subsequent to the present study field work in 2004, larger carnivores (Lions and wild dogs) were reintroduced in Tembe, which should be a key step to restore natural limits to herbivore populations' growth. A follow up study to evaluate whether utilisation decreased as a result would be a worthwhile effort to consider the effectiveness of higher order predators' reintroduction to control herbivore impact on vegetation state and vegetation dynamics.

\section{References}

Barnes, M. E. (2001). Effects of large herbivores and fire on the regeneration of Acacia erioloba woodlands in Chobe National Park, Botswana. African Journal of Ecology, 39, 340-350. http://dx.doi.org/10.1046/j.1365-2028.2001.00325.x

Birkett, A., \& Stevens-Wood, B. (2005). Effect of low rainfall and browsing by large herbivores on an enclosed savannah habitat in Kenya. African Journal of Ecology, 43, 123-130. http://dx.doi.org/10.1111/j.1365-2028.2005.00555.x

Eckhardt, H. C., Wilgen, B. W., \& Biggs, H. C. (2000). Trends in woody vegetation cover in the Kruger National Park, South Africa, between 1940 and 1998. African Journal of Ecology, 38, 108-115. http://dx.doi.org/10.1046/j.1365-2028.2000.00217.x

Gaugris, J. Y. (2008). The impacts of herbivores and humans on the utilisation of woody resources in conserved versus non-conserved land in Maputaland, northern KwaZulu-Natal, South Africa. University of Pretoria, Pretoria, South Africa. Retrieved from http://upetd.up.ac.za/thesis/available/etd-06052008-162658

Gaugris, J. Y., \& van Rooyen, M. W. (2008). A spatial and temporal analysis of Sand Forest tree assemblages in Maputaland, South Africa. South African Journal of Wildlife Research, 38, 171-184. http://dx.doi.org/10.3957/0379-4369-38.2.171

Gaugris, J. Y., \& van Rooyen, M. W. (2011). The effect of herbivores and humans on the Sand Forest species of Maputaland, northern KwaZulu-Natal South Africa. Ecological Research, 26, 365-376. http://dx.doi.org/10.1007/s11284-010-0791-2

Gaugris, J. Y., Vasicek, C. A., \& van Rooyen, M. W. (2012). Herbivore and human impacts on woody species dynamics in Maputaland, South Africa. Forestry An International Journal of Forest Research, 85, 497-512. http://dx.doi.org/10.1093/forestry/cps046

Guldemond, R. A. R., \& van Aarde, R. J. (2007). The impact of elephants on plants and their community variables in South Africa's Maputaland. African Journal of Ecology, 45, 327-335. http://dx.doi.org/10.1111/j.1365-2028.2007.00714.x

Izidine, S., Siebert, S., \& van Wyk, A. E. (2003). Maputaland'slicuati forest and thicket, botanical exploration of the coastal plain south of Maputo Bay, with an emphasis on the Licuati Forest Reserve. Veld \& Flora, 89, 56-61.

Lindenmayer, D. B., Franklin, J. F., \& Fischer, J. (2006). General management principles and a checklist of strategies to guide forest biodiversity conservation. Biological Conservation, 131, 433-443. http://dx.doi.org/10.1016/j.biocon.2006.02.019

Lombard, A. T., Johnson, C. F., Cowling, R. M., \& Pressey, R. L. (2001). Protecting plants from elephants: botanical reserve scenarios within the Addo Elephant National Park, South Africa. Biological Conservation, 102, 191-201. http://dx.doi.org/10.1016/S0006-3207(01)00056-8

Matthews, W. S. (2006). Contributions to the ecology of Maputaland, southern Africa, with emphasis on Sand Forest. PhD thesis. University of Pretoria, Pretoria, South Africa.

Matthews, W. S., van Wyk, A. E., van Rooyen, N., \& Botha, G. A. (2001). Vegetation of the Tembe Elephant Park, Maputaland, South Africa. South African Journal of Botany, 67, 573-594.

Mosugelo, D. K., Moe, S. R., Ringrose, S., \& Nellemann, C. (2002). Vegetation changes during a 36-year period in northern Chobe National Park, Botswana. African Journal of Ecology, 40, 232-240. http://dx.doi.org/10.1046/j.1365-2028.2002.00361.x

O'Connor, T. G., Goodman, P. S., \& Clegg, B. (2007). A functional hypothesis of the threat of local extirpation of woody plant species by elephant in Africa. Biological Conservation, 136, 329-345. 
http://dx.doi.org/10.1016/j.biocon.2006.12.014

Shaw, M. T., Keesing, F., \& Ostfeld, R. S. (2002). Herbivory on Acacia seedlings in an East African savanna. Oikos, 98, 385-392. http://www.jstor.org/stable/3547179

Sheil, D., \& Salim, A. (2004). Forest Tree Persistence, Elephants, and Stem Scars. Biotropica, 36, 505-521. http://dx.doi.org/10.1646/1599

Smith, R. J., Goodman, P. S., \& Matthews, W. (2006). Systematic conservation planning: a review of perceived limitations and an illustration of the benefits, using a case study from Maputaland, South Africa. Oryx, 40, 400-410. http://dx.doi.org/10.1017/S0030605306001232

Styles, C. V., \& Skinner, J. D. (2000). The influence of large mammalian herbivores on growth form and utilization of mopane trees, Colophospermummopane, in Botswana's Northern Tuli Game Reserve. African Journal of Ecology, 38, 95-101. http://dx.doi.org/10.1046/j.1365-2028.2000.00216.x

van Aarde, R. J., \& Jackson, T. P. (2007). Megaparks for metapopulations: Addressing the causes of locally high elephant numbers in southern Africa. Biological Conservation, 134, 289-299. http://dx.doi.org/10.1016/j.biocon.2006.08.027

Walker, B. H. (1976). An approach to the monitoring of changes in the composition and utilisation of woodland and savanna vegetation. South African Journal Wildlife Research, 6, 1-32.

Walpole, M. J., Nabaala, M., \& Matankory, C. (2004). Status of the Mara Woodlands in Kenya. African Journal of Ecology, 42, 180-188. http://dx.doi.org/10.1111/j.1365-2028.2004.00510.x

Western, D. (2006). A half a century of habitat change in Amboseli National Park, Kenya. African Journal of Ecology, 45, 302-310. http://dx.doi.org/10.1111/j.1365-2028.2006.00710.x

Western, D., \& Maitumo, D. (2004). Woodland loss and restoration in a savanna park: a 20-year experiment. African Journal of Ecology, 42, 111-121. http://dx.doi.org/10.1111/j.1365-2028.2004.00506.x

Wiseman, R., Page, B. R., \& O'Connor, T. G. (2004). Woody vegetation change in response to browsing in Ithala Game Reserve, South Africa. South African Journal of Wildlife Research, 34, 25-37. http://hdl.handle.net/10520/EJC117186

\section{Notes}

Note 1. Hypothesis based on combination of known group count, total area count and informed guess.

\section{Copyrights}

Copyright for this article is retained by the author(s), with first publication rights granted to the journal.

This is an open-access article distributed under the terms and conditions of the Creative Commons Attribution license (http://creativecommons.org/licenses/by/3.0/). 